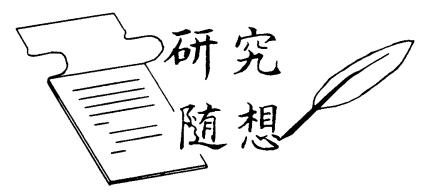

\title{
内燃機関研究を顧みて*
}

日本機械学会論文集 $(B$ 編 $)$

73 巻 735 号 $(2007-11)$

\author{
宮本 \\ 登*1
}

\section{Looking Back on My Engine Research Days}

\author{
Noboru MIYAMOTO*2 \\ ${ }^{* 2}$ Emeritus Professor, Hokkaido University, \\ N-13 W-8, Kita-ku, Sapporo-shi, Hokkaido, 060-8628 Japan
}

Key Words: Internal Combustion Engine, Energy Saving, Exhaust Gas Regulation, Alternative Fuel, Global Warming, Combustion Noise, Measurement

\section{1. は じめに}

私は, 研究生活の大半を大学で過ごし, 内燃機関を 基軸にした仕事を続けてきた。その間, 時世の移り変 わりとともにエンジンを取り巻く状況も，また私の研 究に対する考え方も多少変わってきたように思う. 研究の関連事項も含めて研究生活で思い起こされる こと,また心に強く残っていることなどの一端を述べ させていただきたい.

\section{2. 時世の要求と研究テーマ}

内燃機関との専門的なかかわりは学部の卒論研究が 最初であった，以前から好きではあったが，それを軸 にした研究を長く続けようとは思ってもいなかった。 当時の内燃機関は最近のものに比べればまだ発展過 程にあったのだろうが，それなりに満足すべき性能が 得られており, 早急に研究開発が迫られている状況で はなかったように思う。

ただ，そのころ購入したある刊行誌の特集号で内燃 機関の現状や課題そして将来展望などを目にした際, まだ専門知識不足で内容が十分理解できない部分もあ ったが，なぜか将来への期待感とでも言える感覚に心 が躍ったのを覚えている.「三つ子の魂百まで」と言 うが, 今考えてみると, この若い時代の期待感あるい は感激が内燃機関への探求意欲を支え続けてくれた礎

* 原稿受付 2007 年 8 月 20 日.

*1 正員, 名誉員, フェロー, 北海道大学名誉教授(⿶060-8628 札幌市北区北 13 条西 8).

[著者略歴] 1941 年 1 月 7 日生まれ. 主として内燃機関工学, 燃焼 工学, 石油代替燃料, 反応性ガス力学, レーザ応用計測などの研究 に従事. 2004 年まで北海道大学大学院工学研究科.

E-mail : miyamoto@eng.hokudai.ac.jp
の一つになったと思う。たまたま 1 冊の刊行誌から得 た情報だったが，その力を今更のように感じる.

大学での内燃機関研究が必ずしも容易でない面も多 い中で, 長くその研究を続けることができたのはいく つかの事由が背景にあったためだと思う。

まず，内燃機関の高度化に対する時世の要求が顕在 化し, それに伴って興味を引く研究の課題や目標が 次々と生じてきたこと, 時世の要求とは別に, 熱機関 としての現実的な現象解明の過程で基礎研究の課題が 多く誘起されたこと，そして私の場合，折に触れて指 導と助言をいただいた恩師や先輩，そしてよき同僚， 後輩, 学生に恵まれたことなどがある.

通常, 内燃機関に限らず工業製品や機器類では多様 な要件を総合的にクリアしていることが求められよう が, 内燃機関の場合, それに加えて, 時世の厳しい要 求によって特定の要件に関心が集中し, その高度化が 段階的に求め続けられた経緯がある. 時世要求の代表 例としては, ご承知のように, 1970 年代初頭からの規 制による排出有害ガスの大幅低減, そして 1973 年と 1978 年の第一次と第二次の石油危機を契機とした省 エネルギー化と石油代替燃料の開発・利用促進が挙げ られる。

内燃機関は多くの科学・技術の集積であるため, 視 点を変えれば研究テーマに事欠かない, つまり研究テ ーマの宝庫であったし, 今もそう思っているが, 特に, 時世要求が強化・進行する状況下ではまさに宝庫であ って, 要求の強化に伴って現実的かつ具体的な課題や 目標が次々と創出されると同時に, 新たな研究へのイ ンセンティブが保持され続けた。またその状況では, 研究の成果が具体的に実感しやすく，研究遂行の充実 感を強く感じることも多かった.このことは，時世の 
強い要求に沿った研究における特徵あるいは魅力の一 つとも言えよう.

今ひとつ, 将来も見据えた時世要求として, 昨今の 地球温暖化にかかわる $\mathrm{CO}_{2}$ 低減が挙げられる. 申す までもなく,これは現時世の要求でもあるが, 将来に 向けてこれまで以上に大きな要求になるべきものと思 う.この要求が, 製品やシステムの開発と関連研究の 進展を促し，優れた成果の創出につながることを期待 したい.

\section{3. 時の流れに左右されない研究も}

エネルギー・燃料問題は内燃機関研究でも重要課題 の一つであるが，この問題に対する社会の関心は時世 で著しく変わる．私が直接的に知る限り，その関心が 非常に高まった時機が少なくとも三度ある.

まずは六十数年前の第二次世界大戦のころ，次いで それからほほ 30 年後の第一次および第二次の石油危 機の後, さらにそれから 30 年弱後, 地球温暖化による $\mathrm{CO}_{2}$ 削減と原油価格高騰が世界的関心事となった最 近である.

こうして見ると, この問題への関心は約 30 年また はそれより若干短い周期性を呈しており, その周期で 関心の高揚と衰退が繰返されているように思う.

例えば石油危機の後, エネルギー安全保障確保の点 からも，わが国はエネルギー源の多様化に向けて動き 出し, 天然ガスや原子力等の導入を進めていった。一 方, 内燃機関の燃料については, 第二次大戦終結直後 から活動停止を余儀なくされたような石油代替燃料の 研究, つまりアルコール, バイオマス燃料また石炭液 化燃料等の研究が国内外で再び注目され盛り上がっ た. 北大の内燃機関研究室でも石油系燃料はもとより 各種アルコールや植物油エステルなど広範な燃料を対 象に研究の勢力を注いだ。

その後, 石油の供給と価格が安定するに伴って, 石 油代替燃料への関心が徐々に冷めると, 国内外での代 替燃料研究や利用促進気運もすっかり低調になってい つた.

石油危機から 30 年弱の後, 地球温暖化や昨今の原 油価格高騰の問題台頭によって, エネルギー・燃料問 題への社会要求は再び高揚を呈し, 内燃機関の燃料で は, $\mathrm{CO}_{2}$ 対応も加わりエタノールや植物油エステルな どへの関心が 30 年ほど前と同様に高まってきている。 時世の要求に即した研究では, 有意義な目的を有し また解明すべき点が残っていても, 時世要求の変化に 左右され，その低下によって衰退していく場合が少な くない. 石油代替燃料の研究はそのような様態を呈す
る場合が多く, 研究およびその技術蓄積の効率や迅速 化の点からも，その衰退が残念でならない.

時世の要求に左右される研究とされない研究, 両者 の重要性は単純に語れるものではない. ただ, 石油代 替燃料の研究のように, 本来重要かつ有意義な研究で ありながら, 時世によって要求が変わりまたその影響 を大きく受けがちなものは, 時世要求が多少変化ある いは衰えたとしても研究を継続的に遂行する英断と努 力が望まれよう。そのことが, 効率的かつ迅速で,さ らにより大きな成果につながると思うからである.

\section{4. 現場にも多くの研究テーマや有益な情報が}

ディーゼル機関の試作研究にかかわった時期があっ た。まだディーゼル燃焼のデー夕蓄積も少なかった し，シミュレーション予測技術も確立されていなかっ た.エンジンの燃費率が最良となる燃焼室形状の模索 試験を始めていた。

現場には，試作エンジンを長年手掛けてきた長老級 の技能員がいた，慣らし運転も終わり本試験を始めよ うとするころ，彼が私に圥談のような話しぶりで，こ の燃焼室は燃費がよくないかもしれないなどと予告す るのである．試験回数が増すたびに彼の予告がほぼ当 たることに驚いていた。

遂に，なぜそれがわかるのかを尋ねた，答えは簡 単.「理由はわからないが, 燃焼音が大きなエンジン は燃費がよい」と言う. 彼の長年の経験則であって, エンジンの騒音だけで燃費の善し悪しを予想していた のである．当時, 若くて経験の少ない私には驚きだっ た.

これが燃焼音研究のきっかけとなって, シリンダ圧 力経過のフーリエ周波数分析, つまり CPL(Cylinder Pressure Level) とエンジンの音圧レベルの関係，ま たそれらと熱発生率との関係等について検討を始め た。熱発生率のピークが高くなるに伴って, 特定の周 波数域での CPL とそれに影響される音圧レベルとが ともに高くなること，また当時のエンジンでは熱発生 期間が短縮する場合が多かったため, 熱効率も向上す ることなど，彼の経験則の理論背景がわかった。

現場で経験の長い人は，そこでの経験が浅い私が気 づかない現場の経験則や課題を多く保持していたので ある. 古くから現場 100 回と言って, 技術者や研究者 は現場や実物を何度もしっかりと見ることが大切だと されているが, それと同様に現場の人との交流の中か らもずいぶん多くの貴重な情報や研究課題を学んだよ うに思う。このようなことを経験あるいは実感された 方はずいぶん多いに違いない。 


\section{5. おわりに}

老婆心，いや老爺(ろうや)心だとの非難を恐れずに， 長いようで短かった研究生活のなかで思ったことや経 験したことのいくつかを断片的に記した。

研究に直接関連しないことも含めて感じていたまま を急ぎ書いたため, 読み返してみると内容にコクやキ
レが少ないように思えるところがあるままた，多くの 方が感じており新鮮味に欠けそうな部分や，押しつけ がましい部分などもあるかもしれない。拉許し願いた い.

目を通していただき，何かの糧になりそうなところ がわずかでもあれば幸いである。 